\title{
Influence of moderate electric fields on gelation of whey protein isolate
}

\author{
Rui M. Rodrigues a , Artur J. Martins a , Oscar L. Ramos a, b , F. Xavier Malcata b, c, \\ José A. Teixeira a , António A. Vicente ${ }^{\text {a }}$, Ricardo N. Pereira ${ }^{\text {a, * }}$ \\ ${ }^{a}$ CEB - Centre of Biological Engineering, University of Minho, Campus de Gualtar, 4710-057 Braga, Portugal \\ ${ }^{\mathrm{b}}$ LEPABE - Laboratory of Process Engineering, Environment, Biotechnology and Energy, Rua Dr. Roberto Frias, P-4200-465 Porto, Portugal \\ ${ }^{\text {c }}$ Department of Chemical Engineering, University of Porto, Rua Dr. Roberto Frias, P-4200-465 Porto, Portugal
}

\section{A R T I C L E I N F O}

\section{Article history:}

Received 27 February 2014

Accepted 3 June 2014

Available online 21 June 2014

\section{Keywords:}

Moderate electric field

Whey proteins

$\beta$-Lactoglobulin

Aggregation

Rheology

Gelation

\begin{abstract}
A B S T R A C T
Proteins are one of the food constituents most affected by heating, and some of the changes involve their unfolding, denaturation and gelation. Ohmic heating has often been claimed to improve the quality of foodstuffs due to its uniform heating and (putative) presence of a moderate electric field (MEF). However, this is still subject to discussion, so it is important to determine the effect of ohmic heating and of its MEF upon food constituents. Hence, the aim of this work was to evaluate the effects of MEF on denaturation, aggregation and viscoelastic properties of whey protein isolate (WPI), and compare them with those obtained via conventional heating under identical treatment conditions (up to $30 \mathrm{~min}$ at $85{ }^{\circ} \mathrm{C}$ ). Results have shown that MEF interferes with whey protein unfolding and aggregation pathways at relatively high temperatures. MEF treatments have resulted in WPI solutions possessing more 8 and $10 \%$ of native $\beta$-Lactoglobulin and $\alpha$-Lactalbumin, respectively, after $30 \mathrm{~s}$ of heating at $85^{\circ} \mathrm{C}$, when compared with a conventional heating method. Protein aggregates from MEF-treated WPI solutions presented a maximum increase in size of $78 \mathrm{~nm}$, whereas conventional heating produced an increase of $86 \mathrm{~nm}$. Unlike in conventional heating, aggregation of whey proteins during MEF was not sufficiently strong to form a true elastic gel network, since decreases in both storage and loss modulus were observed following MEF treatment. Our results suggest that MEF may provide a novel method for production of a whey protein matrix with distinctive gel-forming properties.
\end{abstract}

๑ 2014 Elsevier Ltd. All rights reserved.

\section{Introduction}

Whey proteins have increasingly been used as nutritional and a functional ingredients in several food formulations, particularly in the form of dry whey, such as whey protein concentrate (WPC) and whey protein isolate (WPI). The functionality of whey ingredients is determined by changes in their physical and chemical properties during manufacture that commonly include such thermal processing as pre-heating, pasteurization or sterilization. $\beta$-Lactoglobulin $(\beta-\lg )$ is the most abundant globular protein found in whey, thus overriding functional (e.g. gelation and emulsification) and nutritional properties of whey derivatives (Lefevre, Subirade, \& Pezolet, 2005). The effects of heat on denaturation of pure and enriched fractions of $\beta-\lg$ has been extensively reported (Nicorescu

\footnotetext{
* Corresponding author.

E-mail addresses: rncpereira@hotmail.com,_rpereira@deb.uminho.pt
} (R.N. Pereira). et al., 2008). It is known that heating at high temperatures $\left(>60^{\circ} \mathrm{C}\right)$ produces thermal denaturation of globular whey proteins.

The process of denaturation of globular whey proteins is assumed to consist of at least two steps: a partial unfolding of the native protein, and a subsequent aggregation of unfolded molecules (Nielsen, Singh, \& Latham, 1996). In particular, unfolding of the native conformation of globular whey proteins at neutral $\mathrm{pH}$ leads to exposure of free sulfhydryl groups $(\mathrm{SH})$ and hydrophobic amino acid side-chains, normally occluded within bovine serum albumin (BSA) and $\beta$-lg (Kazmierski \& Corredig, 2003; Schmitt et al., 2009; Shimada \& Cheftel, 1989). With further heat treatment, free SH may rapidly interchange with existing disulfide bonds to generate new inter- and intramolecular disulfide bonds that will engage toward protein aggregation (Fairley, Monahan, German, \& Krochta, 1996; Schokker, Singh, Pinder, \& Creamer, 2000). The formation of intermolecular disulfide bonds by sulfhydryl-disulfide interchange is considered one of the major mechanisms of protein aggregation, and is mainly governed by formation 
of $\beta$-lg oligomers that combine into large aggregates (Havea, Singh, \& Creamer, 2002).

However, the mechanism of protein unfolding and aggregation is complex and may be influenced by many factors, such as electrostatic and hydrophobic interactions, hydrogen bonding and disulfide cross-linking (Havea et al., 2002; Kazmierski \& Corredig, 2003; Mulvihill, Rector, \& Kinsella, 1990). Several studies have shown that the processes of protein unfolding and aggregation occur to different extents depending on the conditions prevailing in the aqueous solution (e.g. $\mathrm{pH}$, ionic strength, ionic calcium, fat content, presence of lactose and protein composition/concentration), and heating treatments (Anema \& Li, 2003; Dalgleish \& Banks, 1991; Law \& Leaver, 2000; Nicorescu et al., 2008; Verheul, Roefs, \& de Kruif, 1998).

Ohmic heating $(\mathrm{OH})$ has been receiving increased attention due to its uniform transmission of thermal energy and extremely rapid heating rates that enable high temperatures to be applied without inducing coagulation or excessive denaturation of the constituent proteins (Parrot, 1992). In this sense, this technology provides processed products of higher quality (i.e. where such thermal labile compounds as proteins and vitamins can be preserved) than those obtained by conventional heating technologies (Castro, Teixeira, Salengke, Sastry, \& Vicente, 2003; Machado, Pereira, Martins, Teixeira, \& Vicente, 2010; Parrot, 1992). During OH treatment, electric current passes through food that behaves as a resistor in an electrical circuit, and heat is internally generated according to Joule's law (De Alwis \& Fryer, 1990). OH technology can be distinguished from other electrical heating methods: by a) presence of electrodes contacting the foods; b) frequency range applied (from 50 to $25,000 \mathrm{~Hz}$ ); and c) unrestricted, and typically sinusoidal waveform. $\mathrm{OH}$ is also known by the name of moderate electric fields (MEF) due to the application of an electric field of relatively low intensity (arbitrarily defined between 1 and $1000 \mathrm{~V} \mathrm{~cm}^{-1}$ ) aiming at controlling permeabilization of membranes and other non-thermal effects (Machado et al., 2010). However, only a few scientific and technical works have focused on the effects of MEF upon enriched fractions of $\beta-\lg$ (which is the whey protein most susceptible to heat treatments). Recently, it was shown that MEF may lead to protein conformational disturbances during heat-induced denaturation of WPI (Pereira, Souza, Cerqueira, Teixeira, \& Vicente, 2010; Pereira, Teixeira, \& Vicente, 2011). Hence, is expected that MEF will influence protein aggregation kinetics and gelation, and accordingly affect WPI functional properties. Knowledge of WPI aggregation and gelation behavior upon MEF treatment would be of great significance to the food industry once this whey product is more often used than pure fractions of proteins essentially due to low cost and high availability. Despite WPC being considered the most widespread ingredient, the study of heat-induced aggregation of WPC is usually hindered by the presence of high quantities of fat, lactose and other impurities, which can modify the aggregation behavior and the role of the primary functional proteins (Kazmierski \& Corredig, 2003). The objective of this work was therefore to evaluate the formation of soluble whey protein aggregates from WPI, under the presence and absence of MEF at almost neutral $\mathrm{pH}$ conditions. Fine-stranded WPI gels were also produced under acidic conditions, and characterized through small amplitude oscillatory dynamic measurements - in an attempt to provide new insights about MEF effects upon non-covalent protein interactions.

\section{Material and methods}

\subsection{Whey protein isolate}

WPI powder (Lacprodan DI-9212) used was kindly supplied by Arla Foods Ingredients (Viby, Denmark), and was essentially free of lactose ( $\max 0.5 \%$ ) and fat ( $\max 0.2 \%$ ), with a protein content of $91 \%$ (of dry weight). Protein composition of WPI powder was determined by reverse-phase high-performance liquid chromatography (RP-HPLC): $\alpha$-lac $22.8 \%$, BSA $1.7 \%, \beta-\lg A 44 \%, \beta-\operatorname{lgB} 30.7 \%$ and immunoglobulins (IG) $1.1 \%$ on a protein basis. The amount of proteins considered to be in their "native" state (i.e. soluble at pH 4.6) was $85 \%$ of the total protein content (Pereira et al., 2011).

\subsection{Whey protein solutions}

Protein stock solutions of 3 and 10\% (w/w) were prepared by dissolving the WPI powder in 50 and $20 \mathrm{mM}$ sodium phosphate buffer $(\mathrm{pH}=6)$, respectively. Both WPI solutions were then stirred continuously overnight at refrigeration temperature $\left(5^{\circ} \mathrm{C}\right)$, to ensure full rehydration. For studies of protein unfolding, denaturation and production of soluble protein aggregates, WPI solution at $3 \%(\mathrm{w} / \mathrm{w})$ was prepared with final $\mathrm{pH}$ adjusted to 6.8 with $1 \mathrm{M}$ of $\mathrm{NaOH}$ (Merck, Germany). It has been shown that, when WPI solutions of low protein concentration (1-3\%) heated under neutral $\mathrm{pH}$, small amounts of added salts, lead to the formation of soluble protein aggregates via both disulfide and hydrophobic interactions (Purwanti et al., 2011; Ryan et al., 2012; Schmitt, Bovay, Rouvet, Shojaei-Rami, \& Kolodziejczyk, 2007). For the development of protein gel, was used the WPI solution at $10 \%(\mathrm{w} / \mathrm{w})$ and final $\mathrm{pH}$ was adjusted to 3.0 with $1 \mathrm{M}$ of $\mathrm{HCl}$ (Merck, Germany). Heating WPI with high protein concentration (8-11\%) and under acidic conditions can yield a gel stabilized by non-covalent bonding (Aymard, Nicolai, Durand, \& Clark, 1999; Otte, Zakora, \& Qvist, 2000). Electrical conductivity of the prepared WPI solutions ranged approximately from ca. 1000 to $1500 \mu \mathrm{S} \mathrm{cm}^{-1}$, which allowed $\mathrm{OH}$ effect to be observed.

\subsection{Heating units}

\subsubsection{Conventional heating ( $\mathrm{COV})$}

Experiments were performed in a double-walled water-jacketed reactor vessel ( $3 \mathrm{~mm}$ of internal diameter and $100 \mathrm{~mm}$ height), as reported previously (Pereira et al., 2010). Treatment temperature was controlled by circulating thermo-stabilized water from a bath (set at the same temperature as that selected for the treatment) in order to better control temperature. A magnetic stirrer was introduced inside the reactor vessel to homogenize the solution and improve heat transfer during the heating cycle. Temperature evolution was measured with a type-K thermocouple $\left(1{ }^{\circ} \mathrm{C}\right.$, Omega, 709, U.S.A.), placed at the geometric center of the sample volume and connected to a data logger (National Instruments, USB-9161, U.S.A.) - working with Lab View 7 Express software (National Instruments, NI Data logger).

\subsubsection{Moderate electric fields (MEF)}

MEF treatments were performed in a cylindrical glass reactor (30 cm total length and an inner diameter of $2.3 \mathrm{~cm}$ ), with two stainless steel electrodes placed at each edge isolated by polytetrafluoroethylene (PTFE) caps, as described elsewhere (Pereira et al., 2010, 2011). A gap of $10 \mathrm{~cm}$ between the electrodes (the treatment chamber) was used for the experiments. The supplied voltage, and consequently temperature were controlled through the use of a function generator (Agilent 33,220 A, Bayan Lepas, Malaysia; $1 \mathrm{~Hz}-25 \mathrm{MHz}$ and $1-10 \mathrm{~V}$ ) connected to an amplifier system (Peavey CS3000, Meridian, MS, USA; 0.3 V-170 V). During heating phase and holding treatment, the MEF applied varied from 15 to $22 \mathrm{~V} \mathrm{~cm}^{-1}$ and 4 to $8 \mathrm{~V} \mathrm{~cm}^{-1}$, respectively, whereas electrical frequency was of $25 \mathrm{kHz}$. At this high frequency, $(25 \mathrm{kHz}$ ), electrochemical reactions at the electrode interface are reduced, thus minimizing potential corrosion and leakage of metals to the 
medium (Pataro et al., 2014; Pinto et al., 2013). Temperature measurement was performed as previously described for conventional heating. A data logger was employed to record continuously and simultaneously voltage, and current intensity across the samples during heating.

\subsubsection{Heat treatments}

WPI dispersions were heated through COV and MEF at a holding temperature of $85{ }^{\circ} \mathrm{C}$. Both heating treatments were performed with heating rate of $19.1 \pm 0.2{ }^{\circ} \mathrm{C} \mathrm{min}-1$ and held constant at $85{ }^{\circ} \mathrm{C}$ for $30 \mathrm{~min}$. At different holding time intervals $(5,10,15,20$ and $30 \mathrm{~min}$ ), samples were removed and cooled immediately in ice water at $4{ }^{\circ} \mathrm{C}$ for $10 \mathrm{~min}$. A close similarity of the temperature profiles was obtained during both COV and MEF treatments (see Appendix A, Fig. A.1). This close pairing of heating rate and holding temperature is always a necessary condition to evaluate the nonthermal effects of MEF heating (Pereira et al., 2011).

\subsection{Measurements}

\subsubsection{Reactivity of free sulfhydryl (SH) groups}

The reactivity of free sulfhydryl (SH) groups on WPI solution was determined immediately after heat treatments using Ellman's 5,5'dithiobis-2-nitrobenzoicacid (DTNB) method, as described previously (Pereira et al., 2010). DTNB reacts with thiol compounds from whey proteins to produce $1 \mathrm{~mol}$ of $p$-nitrothiophenol anion $/ \mathrm{mol}$ of thiol (Ellman, 1959), thus giving rise to a yellow color. During heating treatments, WPI samples of $100 \mu \mathrm{L}$ were taken at different holding times (5-30 min) and diluted to $1 \mathrm{ml}$ with phosphate buffer ( $5 \mathrm{mM}, \mathrm{pH} 8.0$ ). To these solutions, was added $12 \mu \mathrm{L}$ of $5 \mathrm{mM}$ of DTNB (Sigma-Aldrich, Spain), prepared in $\mathrm{pH} 8.0$ phosphate buffer. Color development was allowed to proceed for $40 \mathrm{~min}$, and absorbance of samples was read on a microplate reader (Biotech Synergy HT) at $412 \mathrm{~nm}$. Concentration of free SH groups was calculated using a standard curve of L-cysteine (Sigma-Aldrich, Spain) at $\mathrm{pH} 8.0$, in the range of $12-95 \mu \mathrm{M}$.

\subsubsection{Reversed-phase high-performance liquid chromatography (RP-HPLC)}

The level of soluble native whey protein in the unheated and heated WPI solutions was evaluated by RP-HPLC. Denatured whey proteins were removed from the WPI solutions by adjusting the $\mathrm{pH}$ to 4.6, as described before (Pereira et al., 2011). The samples were held for $30 \mathrm{~min}$, and then centrifuged at $15,558 \mathrm{~g}$ for $5 \mathrm{~min}$ in a Mikro 120 Microfuge centrifuge and filtered through filter paper (S \& S Number 605). The filtrate containing the soluble (undenatured) whey proteins was injected in a reverse phase column C18 Symmetry 300 , Waters USA ( $5 \mathrm{~mm}, 300 \AA, 250 \times 4.2 \mathrm{~mm}^{2}$ i.d.), installed in a liquid chromatography system formed by an intelligent HPLC pump PU-2080 Plus, a 3-Line Degasser DG-2080-53, and a UV-970 detector (Jasco, Japan). A Symmetry guard-column (Waters, USA) was used as pre-column. Gradient elution was carried out with a mixture of two solvents (Ferreira, Mendes, \& Ferreira, 2001): solvent $A$ was $0.1 \%$ trifluoroacetic acid (TFA) in water, and solvent B was $0.1 \%$ TFA in a mixture of $95 \%$ aqueous acetonitrile and $5 \%$ water. The column was used at room temperature, the effluent was monitored at $280 \mathrm{~nm}$ and the total run time was $20 \mathrm{~min}$. Standard calibration curves were produced by the external standard method with solutions that contained pure bovine $\beta-\lg A, \beta-\lg B$ and $\alpha$-lac in the range of $0.20-7.0 \mathrm{mg} \mathrm{ml} \mathrm{m}^{-1}, 0.30-9.4 \mathrm{mg} \mathrm{ml}^{-1}$ and $0.03-3.3 \mathrm{mg} \mathrm{ml}^{-1}$, respectively. At these concentration ranges, a linear relationship between the concentrations of $\beta$-lg and $\alpha$-lac was observed (results not shown). The identification of protein peaks was made by comparison of the retention times with those of the corresponding standards, which in order of increasing time were 8.6, 9.7 and $10.0 \mathrm{~min}$ for $\alpha-\operatorname{lac}, \beta-\lg \mathrm{A}$ and $\beta-\lg B$ (see Appendix A, Fig. A.2).

\subsubsection{Native polyacrylamide gel electrophoresis (Native-PAGE)}

In order to evaluate the heat treatment effects on denaturation and aggregation patterns of whey protein subunits, unheated and heated WPI samples were analyzed using Native-PAGE or "nondenaturing" gel electrophoresis. Native-PAGE analyses were carried out using the Mini-Protean II dual slab cell system equipped with a PAC 300 power supply (Bio-Rad Laboratories, Hercules, CA, USA). The resolving and stacking gel contained 10 and $3.7 \%$ of polyacrylamide, respectively. Whey protein samples were mixed with twice their volume of a non-reducing loading buffer of TRIS $0.5 \mathrm{~mol} \mathrm{~L}^{-1}$ at (pH 6.8, 50\% glycerol and $0.02 \%$ bromophenol blue). The gels were maintained overnight in $50 \%$ ethanol and $10 \%$ of acetic acid solution, stained with Comassie Brilliant Blue (R250) solution and destained with a $5 \%$ ethanol and $7.5 \%$ acetic acid solution. The integrated intensities of whey protein bands were determined using the Bio-Rad software "Bio-Rad Quantity One", associated with a GS-800 Densitometer (Bio-Rad Laboratories, Hercules, CA, USA). The quantity of each protein was determined as a percentage of that in the unheated samples (Anema \& Li, 2003).

\subsubsection{Particle size analyses}

Particle size measurements were made by dynamic light scattering (DLS) using a Zetasizer Nano (ZEN 3600, Malvern Instruments Ltd., Malvern, U.K.), equipped with a He-Ne laser of $632.8 \mathrm{~nm}$ and $4 \mathrm{~mW}$. Measurements of the dynamics of scattered light were collected applying backscatter detection NIBS (NonInvasive Back-Scatter) at $173^{\circ}$, which reduces multiple scattering and allows higher concentrations to be measured. Samples of $1 \mathrm{ml}$ of unheated (control) and heated (by COV and MEF) WPI solutions were poured into disposable sizing cuvettes and measurements were carried out, at least, in triplicate. The temperature of the cell was maintained at $25 \pm 0.5{ }^{\circ} \mathrm{C}$ during measurement. Average diffusion coefficients were determined by the method of cumulants fit and were translated into average particle diameters (Z-value) using Stokes-Einstein relationship (Anema \& Li, 2003). Polydispersity index (PDI) derived from cumulants analysis of the DLS measurements was also evaluated and describes the width or the relative variance of the particle size distribution. On the basis of previous works (Pereira et al., 2010, 2011), the variable parameters chosen for the formation of soluble whey protein aggregates (i.e. protein concentration, $\mathrm{pH}$, buffer capacity and heating conditions) were selected to avoid coagulation or gel formation during heating, as this would impair size measurements.

\subsubsection{Dynamic rheological measurements}

Acidic WPI solutions at $10 \%$ of protein were heat-treated in order to induce formation of fine-stranded translucent gels (Errington \& Foegeding, 1998). Gels were cooled in an ice water bath for $30 \mathrm{~min}$, and held in the tubes overnight at $4{ }^{\circ} \mathrm{C}$ prior to rheological measurements. Small amplitude oscillatory dynamic rheological measurements were then performed on WPI gels. Measurements of elastic $\left(G^{\prime}\right)$ and viscous $\left(G^{\prime \prime}\right)$ moduli were recorded in the oscillatory mode as a function of time, at intervals of $30 \mathrm{~s}$. The oscillation stress amplitude was set at $0.1 \%$ and the frequency at $1 \mathrm{~Hz}$. Stress sweeps were applied to check that data were acquired within the linear viscoelastic region.

\subsubsection{Phase-contrast light microscopy}

Microscopy was used to observe the physical structure of gels as described. One drop of WPI gel treated by COV or MEF was placed on acetone-cleaned microscope slides, and covered with a cover slip. Analyses were performed using an inverted microscope (Carl Zeiss, 


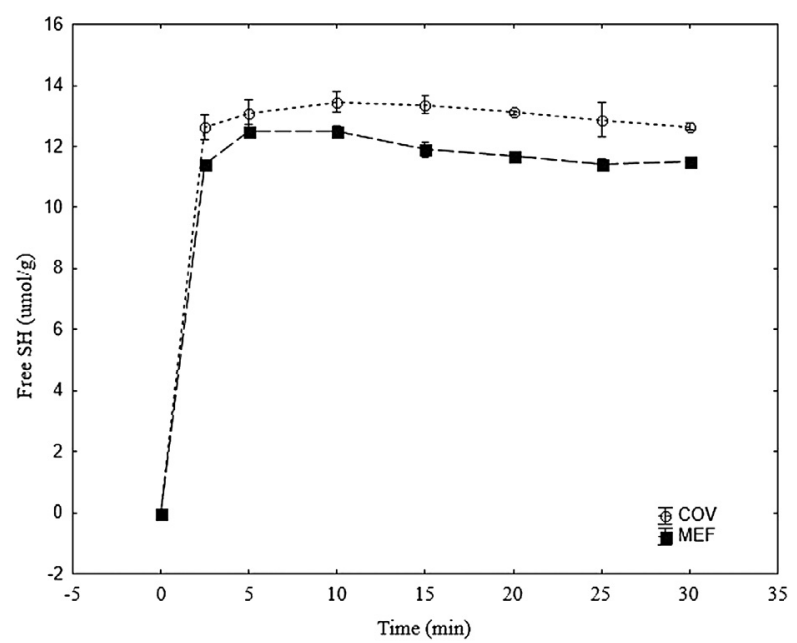

Fig. 1. Concentration of free sulfhydryl groups $(\mathrm{SH})$ as a function of holding time during conventional (COV) and moderate electric fields (MEF) thermal treatments, at a holding temperature of $85^{\circ} \mathrm{C}$.

Axiovert 40, Ontario, Canada), equipped with a digital camera (Nikon D60) and using the phase contrast field at $40 \times$ magnification.

\subsection{Statistical analysis}

All statistical analyses involving experimental data were performed using Statistica software version 10.0.228.8 (StatSoft Inc.). Statistical significance was determined by Student's $t$ and Turkey's tests, using 0.05 as preselected level of significance. Unless otherwise stated, all the following experiments were run at least in triplicate, and all measured parameters are means of four experimental points.

\section{Results and discussion}

\subsection{Unfolding of whey proteins}

$\beta$-Lactoglobulin contributes with $90-95 \%$ of the SH groups found in skim milk, and milk-derived protein ingredients (OwusuApenten \& Chee, 2004). Thermal processing at denaturation temperatures (above $60{ }^{\circ} \mathrm{C}$ ) involves changes in protein conformation that convert masked $\mathrm{SH}$ groups to free $\mathrm{SH}$ ones, thus becoming available for the formation of covalent disulfide bonds. The reactivity of free $\mathrm{SH}$ groups, measured at $85{ }^{\circ} \mathrm{C}$ under $\mathrm{COV}$ and MEF treatments as a function of time, is shown in Fig. 1. Activation and reactivity of SH groups in WPI solutions were observed upon both treatments (COV and MEF), and essentially reached a plateau value after early stages of heating (first $5 \mathrm{~min}$ ). By $10 \mathrm{~min}$ of heating, the differences between both treatments became significant $\left({ }^{*} p<0.05\right)$, and it was observed that COV samples presented more
$1.2 \mu \mathrm{mol}$ of SH per $\mathrm{g}$ of WPI than samples treated by $\operatorname{MEF}\left({ }^{*} p<0.05\right)$. These results do somehow agree with those previously reported, where COV heating led to higher reactivity of SH groups (more $2.2 \mu \mathrm{mol}$ of $\mathrm{SH}$ per $\mathrm{g}$ of WPI) than samples treated by MEF $\left({ }^{*} p<0.05\right)$, under the same heating temperature and time conditions $\left(85^{\circ} \mathrm{C}\right.$ for $30 \mathrm{~min}$ ) (Pereira et al., 2010). These results suggest that structural transitions and unfolding of $\beta$-lg were less favored during MEF treatment, possibly due to less aggressive thermal effects associated with the presence of an alternating electric field. Denaturation kinetics are primarily driven by covalent bonding of unfolded proteins, which in turn is closely related to the availability and reactivity of the free SH groups of unfolded proteins (Kroslak, Sefcik, \& Morbidelli, 2007). Therefore, the lower reactivity of free SH observed during MEF may contribute to low whey denaturation rates at early stages of the process and change the role of whey protein aggregation. Overall, calculated SH levels were slightly higher than the published values (Aboshama \& Hansen, 1977; Cosio, Mannino, \& Buratti, 2000; Owusu-Apenten, 2005), probably due to the use of WPI instead of skim milk fractions, and to different analytical and quantification techniques being employed. Nevertheless, the results obtained indicate unmasking and activation of SH groups in whey proteins upon extended heat treatment, as observed and reported in previous studies at temperatures above $70{ }^{\circ} \mathrm{C}$ (Koka, Mikolajcik, \& Gould, 1968; Owusu-Apenten, 2005; Owusu-Apenten \& Chee, 2004).

\subsection{Whey protein denaturation}

In order to study the influence of MEF and COV treatment upon extent of protein denaturation, samples from the same batch of WPI solution were analyzed before and during the heating process through RP-HPLC. The mean results and corresponding standard errors expressing heat-induced denaturation of whey proteins as a function of heating treatment are presented in Table 1. As expected, concentration of soluble native whey proteins decreased with an increase in holding time, and the degrees of denaturation were higher than $90 \%$ after $5 \mathrm{~min}$ of heating at $85{ }^{\circ} \mathrm{C}$. The denaturation levels observed were slightly higher (10-15\%) than those observed elsewhere (Anema \& Li, 2003; Dannenberg \& Kessler, 1988; Oldfield, Singh, Taylor, \& Pearce, 1998). This can be explained by the fact that, during processing to obtain WPI powder, partial unfolding of the major whey proteins may occur that results in a more rapid denaturation on the subsequent heating treatments (Anema \& McKenna, 1996). Moreover, these authors studied the disappearance of native whey proteins in skim raw milk fractions, and suggested that some of the constituents may have influenced the rate of denaturation.

When COV and MEF treatments were compared, significant differences $\left({ }^{*} p<0.05\right)$ were found between the native total contents of whey immediately after $30 \mathrm{~s}$ of heating at $85^{\circ} \mathrm{C}$. In fact, after a holding time of $30 \mathrm{~s}$, WPI solutions presented more 8 and $10 \%$ of soluble native $\beta$-lgA and $\alpha$-lac, respectively, than WPI

Table 1

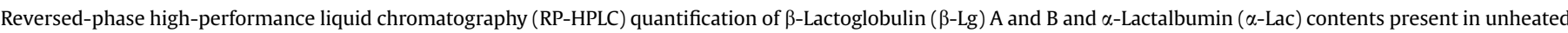

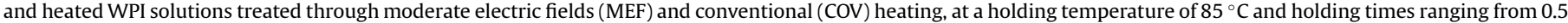
to $10 \mathrm{~min}$.

\begin{tabular}{|c|c|c|c|c|c|c|}
\hline Holding (min) & \multicolumn{2}{|c|}{$\alpha$-lac $\left(\mathrm{mg} \mathrm{ml}^{-1}\right)$} & \multicolumn{2}{|c|}{$\beta-\lg A\left(\mathrm{mg} \mathrm{ml}^{-1}\right)$} & \multicolumn{2}{|c|}{$\beta-\lg B\left(\mathrm{mg} \mathrm{ml}^{-1}\right)$} \\
\hline \multirow[t]{2}{*}{0} & \multicolumn{2}{|l|}{$2.23 \pm 0.12$} & \multicolumn{2}{|l|}{$7.53 \pm 0.29$} & \multicolumn{2}{|l|}{$6.45 \pm 0.15$} \\
\hline & $\mathrm{COV}$ & MEF & $\mathrm{COV}$ & MEF & $\mathrm{COV}$ & MEF \\
\hline 0.5 & $0.42 \pm 0.02^{\mathrm{a}}$ & $0.64 \pm 0.00^{b}$ & $3.00 \pm 0.11^{a}$ & $3.58 \pm 0.09^{b}$ & $1.44 \pm 0.12^{\mathrm{a}}$ & $1.75 \pm 0.05^{\mathrm{a}}$ \\
\hline 5 & $0.06 \pm 0.00^{c}$ & $0.06 \pm 0.00^{c}$ & $0.89 \pm 0.04^{c}$ & $0.93 \pm 0.05^{c}$ & $0.41 \pm 0.00^{\mathrm{b}}$ & $0.43 \pm 0.00^{\mathrm{b}}$ \\
\hline 10 & $0.04 \pm 0.00^{d}$ & $0.04 \pm 0.00^{d}$ & $0.46 \pm 0.01^{d}$ & $0.45 \pm 0.01^{d}$ & $0.33 \pm 0.00^{c}$ & $0.34 \pm 0.00^{c}$ \\
\hline
\end{tabular}

For each whey protein, means with different superscripts are significantly different $\left({ }^{*} p<0.05\right)$. 
solutions treated by COV under identical thermal profiles $\left({ }^{*} p<0.05\right)$. These variations were dissipated for extended holding times (5 and $10 \mathrm{~min}$ ), where no significant differences were observed between these treatments $\left({ }^{*} p>0.05\right)$. The results outlined in Table 1 also indicate that the disappearance of native $\beta$-lg was faster for $\beta-\lg B$ than for $\beta-\lg A$, which is in agreement with previous works (Croguennec, O'Kennedy, \& Mehra, 2004; Nielsen et al., 1996).

Isolation and quantification of native whey proteins through RPHPLC involves precipitation at low $\mathrm{pH}$ that can induce protein denaturation or produce low yields (Lozano, Giraldo, \& Romero, 2008). Therefore, the influence of MEF on the extent of whey protein denaturation was also assessed by Native-PAGE. This method is considered fast and versatile for the quantification of whey proteins, and reflects the exact amounts of native proteins in samples submitted to different thermal treatments (Lin, Sun, Cao, Cao, \& Jiang, 2010), by separating proteins in their native form based on charge, hydrodynamic size and shape of the molecule. Fig. 2 shows that, through Native-PAGE under non-reducing conditions, at least four major bands appear: $\beta-\lg A, \beta-\lg B, \alpha-\operatorname{lac}$ and BSA. The whey protein bands on the resultant native gels were identified by concurrent electrophoresis of $\beta$-lg and $\alpha$-lac samples. Some other protein bands (such as BSA) were identified by comparing the results with reported patterns (Glibowski, Mleko, \& WesolowskaTrojanowska, 2006; Havea, Singh, Creamer, \& Campanella, 1998).

The results of Native-PAGE were quantified with gel densitometry, in attempts to measure the loss of the major native whey proteins. Since the amount of bound dye is proportional to the protein content, changes in the amount of protein fractions can be detected through the integrated intensities of whey protein bands (Anema \& Li, 2003; Pásztor-Huszár, 2008; Schokker, Singh, Pinder, Norris, \& Creamer, 1999). Table 2 displays the contents, in percentage of native whey proteins, determined by Native-PAGE during heating treatments. In general, both COV and MEF treatments have reduced considerably the contents of native whey proteins, and the denaturation levels observed were in good agreement with published literature (Anema \& Li, 2003). In both heat-treated WPI solutions, the loss of BSA was faster than that of $\beta$-lg or $\alpha$-lac, whereas the loss of $\alpha$-lac was faster than that of $\beta$-lg thus agreeing with previous studies performed on whey protein (Havea et al. 2002). In particular, BSA was completely denaturated during the early stages of heating, since the corresponding band was lost after the first 5 min of heating at $85^{\circ} \mathrm{C}$. The decline in native $\beta$-lg was considerably slower than that of $\alpha$-lac; after 15 min of heating at $85^{\circ} \mathrm{C}$, the protein bands associated with native $\beta-\lg A(\sim 14 \%)$ and $\beta$ $\operatorname{lgB}(\sim 6 \%)$ remained in the gel. Conversely, native $\alpha$-lac was completely lost after $10 \mathrm{~min}$ of heating. Isolated $\alpha$-lac is considered one of the least heat-stable of the milk proteins; however, denaturation at relatively high temperatures can be substantially reversible, thus accounting for its apparently high thermal stability observed in bovine milk (Anema \& McKenna, 1996; Larson \& Rolleri, 1955; Lin et al., 2010). However, there are also studies showing that dimeric $\beta$-lg possesses a high stabilization free energy at neutral $\mathrm{pH}$ in phosphate buffer, which can explain the higher heat stability of $\beta$-lg against $\alpha$-lac (Apenten, Khokhar, \& Galani, $2002)$. Results also have shown that $\beta-\lg B$ was irreversibly denatured to a greater extent than $\beta$ - $\lg A$ variant - in agreement with previous results from RP-HPLC. In fact, after $20 \mathrm{~min}$ of holding at $85^{\circ} \mathrm{C}$, only a small amount of native $\beta$-lgA was still present in the gel. This is in agreement with studies showing that $B$ variant is less heat stable than A variant, in the range of temperatures studied; and with realization that, to achieve the same degree of denaturation of $\beta-\lg A$, the holding time had to be increased by $30-40 \%$ as compared to that necessary for the corresponding denaturation of $\beta-\operatorname{lgB}$ (Anema \& McKenna, 1996; Dannenberg \& Kessler, 1988).

In agreement with the previous results obtained through RPHPLC, whey protein denaturation was lower for MEF than COV treatment during the early stages of heating, under identical thermal profiles. MEF treatment determined higher amounts of native whey proteins (i.e. more 8 and $10 \%$ of soluble native $\beta$-lgA and $\alpha$-lac, respectively), than $\mathrm{COV}$, being this difference statistically significant for holding times of $5 \min \left({ }^{*} p<0.05\right)$. This result does not agree with the one obtained through RP-HPLC, where no significant differences were noticed for holding times of 5 min between MEF and COV.

Moreover, denaturation levels observed via RP-HPLC were much higher than those observed by Native-PAGE. Samples heated for 5 min at $85{ }^{\circ} \mathrm{C}$ and analyzed by RP-HPLC showed a rather low percentage of native $\beta-\lg (\sim 8 \%)$, whereas a considerable amount of protein with the same electrophoretic mobility as native $\beta$-lg $(\sim 25-35 \%)$ was still observed through Native-PAGE after the same heat treatment. This could simply be due to a greater sensitivity of PAGE technique, or else indicate that some of the irreversibly altered whey proteins had the same electrophoretic mobility as their native counterparts (Schokker et al., 1999).

Native-PAGE revealed that heating at $85{ }^{\circ} \mathrm{C}$ by COV and MEF, resulted in the disappearance of native $\beta$-lg bands, and the

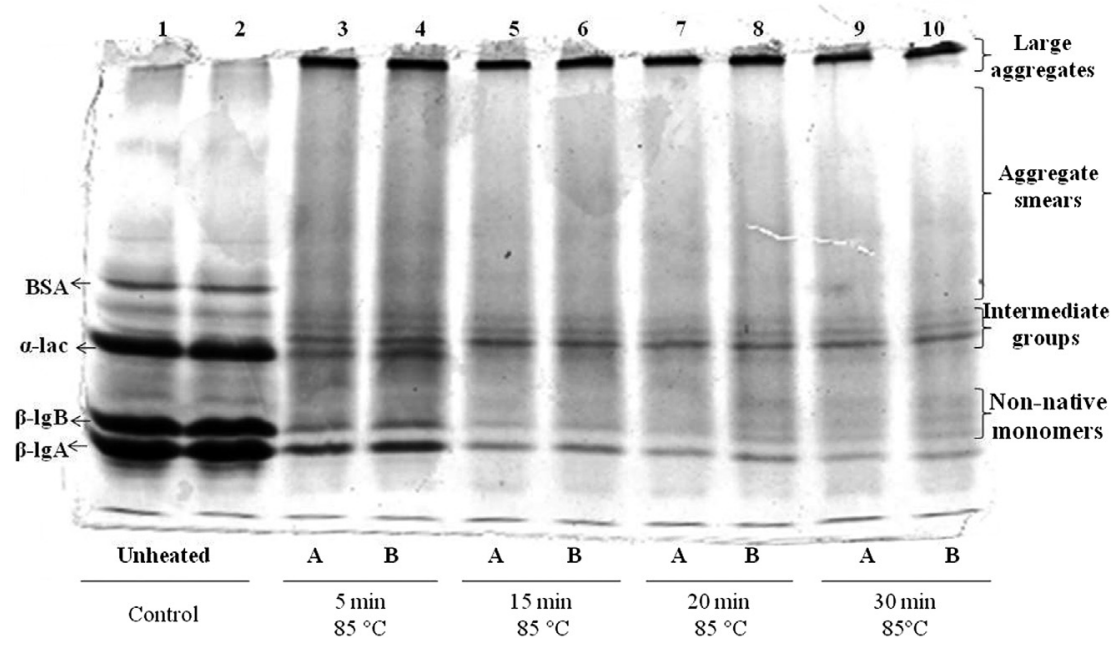

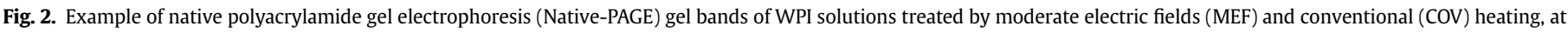
a holding temperature of $85^{\circ} \mathrm{C}$ and holding times ranging from 5 to $30 \mathrm{~min}$. 
Table 2

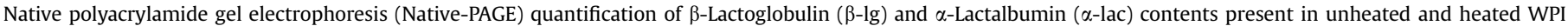
solutions treated via moderate electric fields (MEF) and conventional (COV) heating, at holding temperature of $85{ }^{\circ} \mathrm{C}$ and holding times ranging from 5 to 30 min.

\begin{tabular}{|c|c|c|c|c|c|c|}
\hline \multirow[t]{2}{*}{ Holding (min) } & \multicolumn{2}{|l|}{$\alpha$-lac (\%) } & \multicolumn{2}{|l|}{$\beta-\lg A(\%)$} & \multicolumn{2}{|l|}{$\beta-\lg \mathrm{B}(\%)$} \\
\hline & $\mathrm{COV}$ & MEF & $\mathrm{COV}$ & MEF & $\mathrm{COV}$ & MEF \\
\hline 5 & $6.6 \pm 0.4^{a}$ & $9.0 \pm 0.7^{b}$ & $34.5 \pm 1.0^{\mathrm{a}}$ & $42.8 \pm 2.1^{\mathrm{b}}$ & $21.0 \pm 4.6^{\mathrm{a}}$ & $27.2 \pm 1.5^{\mathrm{a}}$ \\
\hline 15 & nd & nd & $12.5 \pm 0.5^{c}$ & $13.9 \pm 1.9^{\mathrm{c}}$ & $6.0 \pm 1.6^{\mathrm{b}}$ & $5.4 \pm 0.1^{b}$ \\
\hline 20 & nd & nd & $9.9 \pm 1.2^{\mathrm{c}, \mathrm{d}}$ & $10.6 \pm 1.0^{c, d}$ & $3.5 \pm 1.2^{\mathrm{c}}$ & $2.8 \pm 0.3^{c}$ \\
\hline 30 & nd & nd & $5.4 \pm 0.1^{\mathrm{d}}$ & $6.7 \pm 0.5^{d}$ & $1.8 \pm 0.1^{\mathrm{d}}$ & $2.5 \pm 0.1^{\mathrm{d}}$ \\
\hline
\end{tabular}

For each whey protein, means with different superscripts are significantly different $\left({ }^{*} p<0.05\right)$.

nd, not detected.

formation of protein species with lower electrophoretic mobility. Faded bands appeared between native $\beta$-lg and $\alpha$-lac bands, which were identified by several authors as non-native monomers (Manderson, Hardman, \& Creamer, 1998; Schokker et al., 2000). Faint bands in the region between BSA and $\beta$-lg have become distinct after the first $5 \mathrm{~min}$ of heating, and are identified as intermediate protein groups, such as $\beta$-lg dimers and trimers, that were formed during heating (Cho, Singh, \& Creamer, 2003; Havea et al., 2002). Heating at $85{ }^{\circ} \mathrm{C}$ resulted in a sharp decrease in "native-like" $\beta$-lg and $\alpha$-lac bands, and a concomitant appearance of both aggregate smears and high molecular mass protein aggregates bands (Fig. 2); this indicates extensive protein aggregation, and consequently aggregation of $\beta$-lg and $\alpha$-lac (Glibowski et al., 2006; Schokker et al., 2000). Heating $\alpha$-lac is responsible for producing non-native monomeric groups of $\alpha$-lac dimers and larger aggregates. Previous studies showed that the irreversible transformation of $\alpha$-lac into disulphide-bonded dimers, trimers and non-native forms is faster because of the presence of $\beta$-lg. Formation of $\beta$ $\lg : \alpha$-lac disulphide-bonded dimers is also caused by the heat effect (Havea et al., 1998; Hong \& Creamer, 2002).

Protein concentration is an important factor concerning its denaturation by heat because of their tendency to aggregate when at high concentrations. (Glibowski et al., 2006; Schokker et al., 2000; Wehbi et al., 2005). In fact, protein large aggregates were at the top of the resolving gel - characterized by a molecular mass of ca. $250 \mathrm{kDa}$. Molecules with molecular mass above $1000 \mathrm{kDa}$ remained at the top of the wells, and only the molecules up to $250 \mathrm{kDa}$ could enter the resolving gel (Glibowski et al., 2006). The appearance of the large aggregate smear region changed with heating time for both MEF and COV treatments. In general, a maximum increase in the dye intensity of aggregate smear region was observed at 5 min of heating time (Fig. 2, lanes 3 and 4); the samples heated for 30 min showed a less intense aggregate smear band (Fig. 2, lanes 9 and 10). This may be a clue to an increase in the overall size (and molecular weight) of the heat-induced protein aggregates and complexes, which probably become trapped on the top of the stacking wells (Cho et al., 2003; Glibowski et al., 2006).

Both results from RP-HPLC and Native-PAGE indicate that MEF can preserve higher contents of native proteins during early stages of heating than COV (see Tables 1 and 2), which is in agreement with previous results regarding denaturation kinetics of whey proteins (Pereira et al., 2011). This lower denaturation observed during MEF is also supported by results from reactivity of free $\mathrm{SH}$ measurements. Moreover, it was possible to confirm the formation of soluble aggregates of whey proteins upon MEF treatment of WPI solutions through Native-PAGE (Fig. 2).

\subsection{Whey protein aggregation}

It is known that denaturation of $\beta$-lg under neutral $\mathrm{pH}$ and low ionic strength in the temperature range of $60-70{ }^{\circ} \mathrm{C}$ forms transparent dispersions, containing relatively small polymeric protein particles with sizes < 100 nm (Hoffmann, Roefs, Verheul, VanMil, \& DeKruif, 1996; Roefs \& De Kruif, 1994). Native-PAGE provided evidence for the formation of high molecular mass aggregates of whey proteins after heating treatments of WPI solutions at $85^{\circ} \mathrm{C}$ (Fig. 2). However, it was not possible to observe the effect of COV and MEF upon aggregation extent using electrophoresis, because large aggregates were formed and did not penetrate into the resolving gel after 5 min of heating (Fig. 2). Through DLS analysis, it was possible to confirm formation of soluble whey protein aggregates upon heating at $85{ }^{\circ} \mathrm{C}$. The fundamental size distribution generated by DLS is an intensity distribution, which can be converted using Mie theory to a volume distribution - or can be used through the cumulant method to find the mean average $\left(Z_{\mathrm{avg}}\right)$, i.e. the size of a particle that corresponds to the mean of the intensity distribution. $Z_{\text {avg }}$ is beneficial when citing a single average value for the purpose of comparison (Gordon \& Pilosof, 2010).

Fig. 3 shows the size distribution curves obtained for unheated WPI dispersions, initially prepared at $3 \%(\mathrm{w} / \mathrm{v})$, and the size distributions for the same dispersion after heating at $85^{\circ} \mathrm{C}$. In terms of intensity, the size distribution curves (sensitive to particles of large sizes) showed a first population with a maximum located between 2 and $10 \mathrm{~nm}$ (peak 1), a second population with a maximum between 16 and $78 \mathrm{~nm}$ (peak 2), and a final population at $122-712 \mathrm{~nm}$ (peak 3). This polymodal distribution of unheated WPI dispersions agrees with published literature. In particular, non-aggregated whey proteins, such as $\beta$-lg and $\alpha$-lac monomers and dimers, remain below $7 \mathrm{~nm}$ (Gimel, Durand, \& Nicolai, 1994; Nicorescu

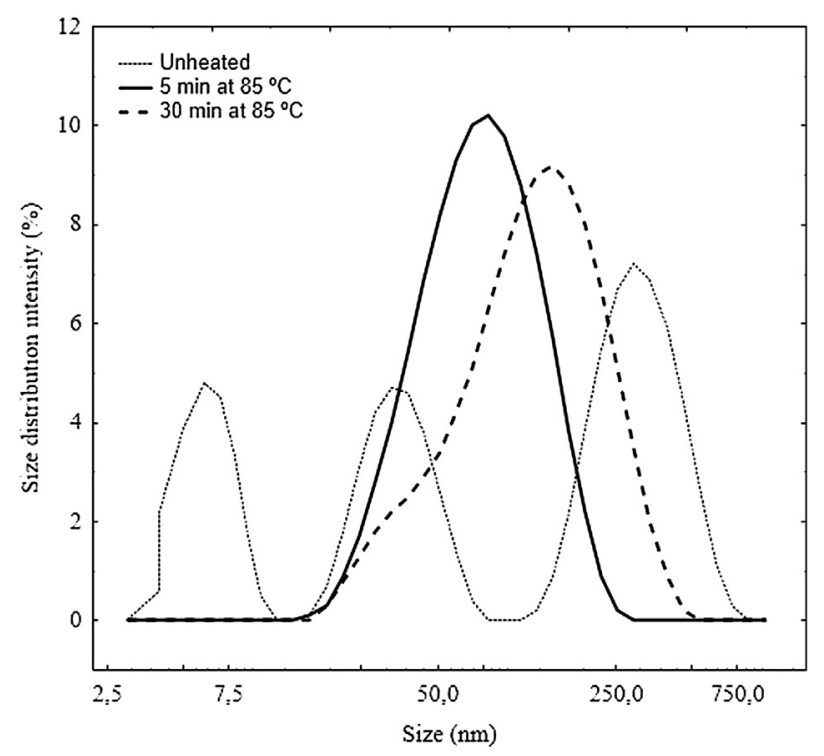

Fig. 3. Examples of particle size distribution intensity curves of whey protein isolate (WPI) solutions obtained via dynamic light scattering measurement, after heating at a holding temperature of $85{ }^{\circ} \mathrm{C}$ for 5 and $30 \mathrm{~min}$. 
et al., 2008; Roefs \& De Kruif, 1994); this corresponds to peak 1 distribution observed in unheated WPI. Peak 2 and 3 correspond to native whey aggregates, which are commonly observed in industrial hydrated WPI (Grácia-Juliá et al., 2008; Nicorescu et al., 2008).

When WPI solutions were heated at $85{ }^{\circ} \mathrm{C}$, the intensity of the size distribution curves unfolded disappearance of peak 1 (observed after 5 min of heating), with a concomitant increase of peak 2 and partial disappearance of peak 3 (see Fig. 3). Peak 3 may correspond to "clumps" of whey proteins that became disaggregated upon heating. Peak 2 distribution was progressively shifted towards larger sizes, ranging from 8 to $130 \mathrm{~nm}$ and 9 to $230 \mathrm{~nm}$, for 5 and $30 \mathrm{~min}$ of heating, respectively. These results are consistent with those by Sharma et al. (Sharma, Haque, \& Wilson, 1996) who observed a sharp decrease in small size particles $(1-9 \mathrm{~nm})$ with a concomitant increase in aggregates of larger sizes $(100-500 \mathrm{~nm})$ upon heating $5 \%(\mathrm{w} / \mathrm{v}) \beta-\lg (\mathrm{pH} 7.0)$ at $70{ }^{\circ} \mathrm{C}$ for 5 min. Grácia-Juliá et al. (2008) also observed that the maximum of peak 2 was progressively shifted towards larger sizes.

Fig. 4 indicates that slight oscillations in the values of electrical conductivity $(\sigma)$ contributed to the different patterns of aggregation observed. These oscillations (ranging from 1000 to $1500 \mu \mathrm{S} \mathrm{cm}^{-1}$ ) can be justified by very small variations on WPI powder weighting, preparation of buffer solution, $\mathrm{pH}$ adjustments or protein solubilization. However, irrespective of the electrical conductivity value, when the size of whey protein aggregates from COV- and MEFtreated solutions were compared, it was possible to observe that MEF produced always smaller structural changes $\left({ }^{*} p<0.05\right)$, particularly after $30 \mathrm{~min}$ of heating. Unheated WPI presented a high
PDI (see Appendix A, Fig. A.3), as a consequence of the polymodal distribution of native WPI solutions. Upon heating, large aggregates have disappeared (corresponding to peak 3); hence, the size distribution became monomodal, and a drastic decrease in PDI was observed. With longer heating, PDI increased slightly to an identical plateau of approximately 0.270 in both heating treatments $\left({ }^{*} p>0.05\right)$ - thus indicating that, within instrumental limits, the distribution was not broadening upon heating.

According to Native-PAGE results, heat-induced whey aggregates started to appear after $5 \mathrm{~min}$ of heating, and became larger with increasing heat time. However, the size increase observed during the first $5 \mathrm{~min}$ represented about $60-70 \%$ of the total size increase found after $30 \mathrm{~min}$ of heating (Fig. 3). The aggregation mechanism of WPI at neutral $\mathrm{pH}$ is close to that of pure $\beta-\mathrm{lg}$ (Mahmoudi, Mehalebi, Nicolai, Durand, \& Riaublanc, 2007). Therefore, this aggregation behavior is considered to be the result of unfolding, and subsequent aggregation of $\beta$-lg, which occur through: disulphide exchange reactions (propagation) (Kazmierski \& Corredig, 2003); reactions between reactive, unfolded intermediates and native $\beta$-lg molecules; and reactions by thiol group-thiol group (termination) of reactive intermediates (Hoffmann et al., 1996; Roefs \& De Kruif, 1994). During thermal exposure at $\mathrm{pH}$ values above the isoelectric point, the unfolding of the protein's native globular structure exposes the hydrophobic region of $\beta$-lg, containing disulphide bonds and the free SH group (Laligant, Dumay, Valencia, Cuq, \& Cheftel, 1991). The reactivity of the SH group for further reactions, such as disulphide exchange, is enhanced at high temperatures such as $85^{\circ} \mathrm{C}$; and, when combined
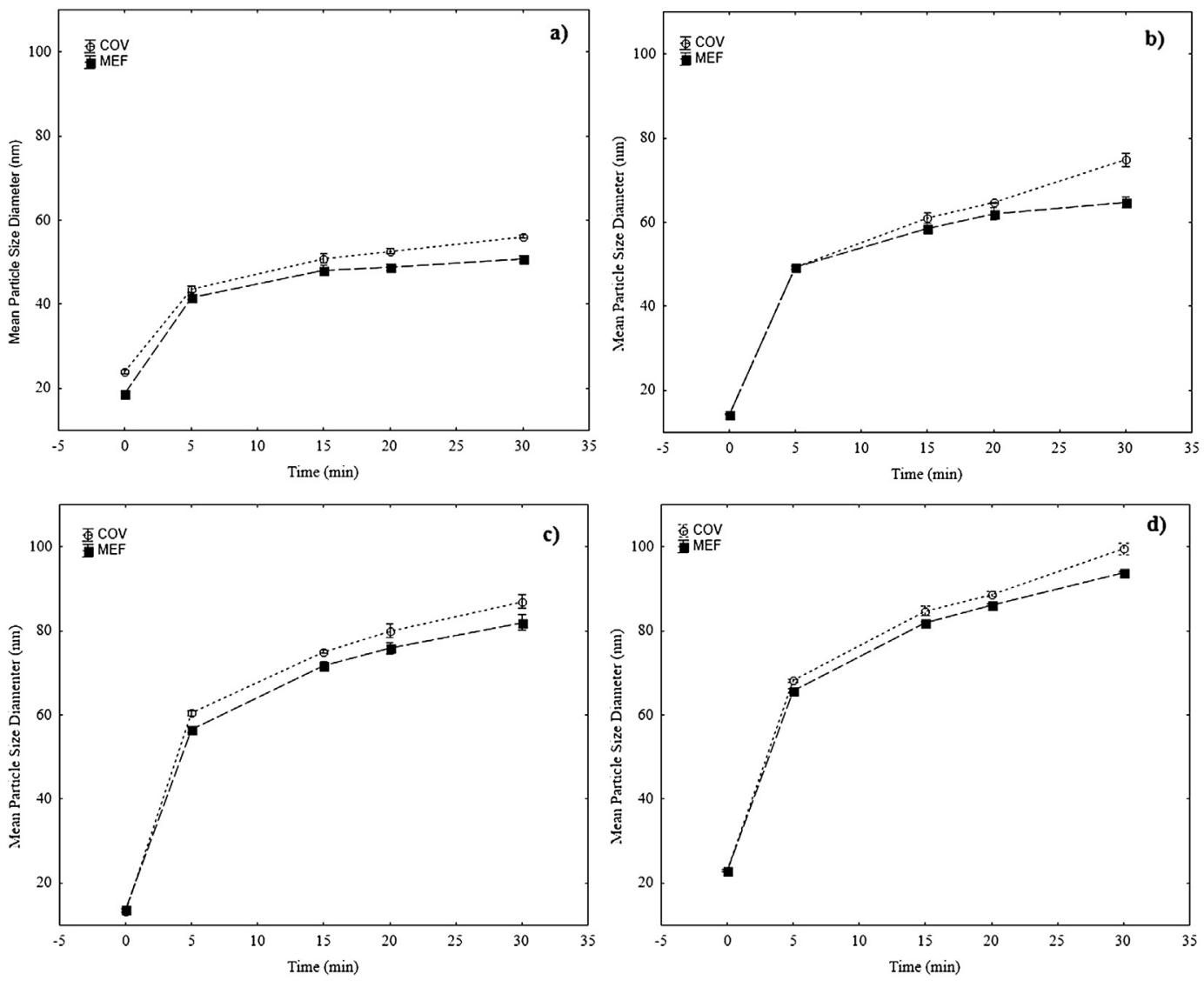

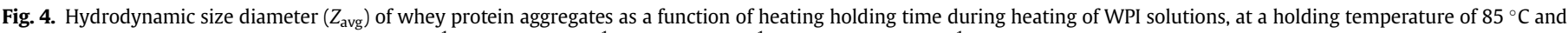
different electrical conductivities: a) $1180 \mu \mathrm{S} \mathrm{cm}^{-1}$; b) $1443 \mu \mathrm{S} \mathrm{cm}^{-1}$; c) $1476 \mu \mathrm{S} \mathrm{cm}^{-1}$; and d) $1533 \mu \mathrm{S} \mathrm{cm}^{-1}$. 
with long heating times, an increase in the probability of collisions leading to increased formation of WPI aggregates occurs (GráciaJuliá et al., 2008; Kazmierski \& Corredig, 2003).

It is also known that irreversible denaturation of whey proteins is characterized by an unfolding (first order-step) followed by aggregation (second-order step) (Tolkach \& Kulozik, 2005). Theoretically speaking, if unfolding of $\beta-\lg$ is enhanced and if heat-treated $\beta$-lg contains a higher amount of free SH groups, the aggregation step will be favored (Sava, Van der Plancken, Claeys, \& Hendrickx, 2005). These observations are consistent with results obtained in this study, as they clearly show that MEF leads to less extensive whey protein aggregation -, in addition to the lower denaturation rates and reactivity to $\mathrm{SH}$, when compared with $\mathrm{COV}$, under identical thermal conditions. In this study, thermal histories of both MEF and COV treatments were made equal, including heating and holding time. Absence of very hot surfaces $\left(T \leq 85{ }^{\circ} \mathrm{C}\right)$ and continuous stirring also assured a maximum similarity between heating methods (see Appendix A, Fig. A.1). Therefore, the different patterns of aggregation observed during MEF can be attributed to factors other than heating kinetics and efficiency. Apparently, MEF effects dictated marked differences in whey protein denaturation $\left({ }^{*} p<0.05\right)$, when compared to those from COV under equivalent heating rates and holding times. As a consequence of this kinetic behavior, MEF lead also to less pronounced aggregation.

\subsection{Whey protein gelation}

The network structure in a heat-induced globular protein gel is strongly dependent on the balance between attractive and repulsive forces among denatured protein molecules during aggregation (Ikeda \& Morris, 2002). Under neutral pH and low ionic strength, there is an increased electrostatic repulsion and formation of covalent disulfide bonds that reduce protein aggregate size (Schmitt et al., 2007). Whey protein aggregates formed under these conditions require higher levels of salts to screen the charge and form gels (Vardhanabhuti \& Foegeding, 1999; Vardhanabhuti, Foegeding, McGuffey, Daubert, \& Swaisgood, 2001). Moreover, the presence of an electric field may induce, together with changes in the reactivity of $\mathrm{SH}$, disturbances on non-covalent interactions between proteins. Therefore, gel formation under conditions that induce protein interactions through non-covalent bonding were promoted in this study.

At acidic $\mathrm{pH}$ (far from the protein isoelectric point, which is $\sim 5.2$ ) and low ionic strength, a gel network form that is composed of fine strands in the order of nanometer in size (Ikeda \& Morris, 2002; Kavanagh, Clark, \& Ross-Murphy, 2000), where intermolecular covalent disulfide bonding is unlikely to occur (Aymard et al., 1999; Otte et al., 2000). WPI fine-stranded and transparent gels were produced at $\mathrm{pH} 3$ after heating at $85{ }^{\circ} \mathrm{C}$ for $30 \mathrm{~min}$.

Fig. 5 shows the frequency sweep of storage $\left(G^{\prime}\right)$ and loss $\left(G^{\prime \prime}\right)$ moduli of WPI gels formed by COV and MEF treatments. For both treatments, $G^{\prime}$ and $G^{\prime \prime}$ exhibited a very weak frequency dependence. COV gels presented always a $G^{\prime}$ larger than $G^{\prime \prime}$ over the entire frequency range; such features are characteristic of a true gel (Eissa, 2005). On the other hand, MEF originated a weaker gel structure than COV treatment, since decreases in both $G^{\prime}$ and $G^{\prime \prime}$ occurred. In addition, MEF resulted in nearly identical values for $G^{\prime}$ and $G^{\prime \prime}$, or alternatively higher $G^{\prime \prime}$ than $G^{\prime}$, thereby demonstrating two important points: 1) the number of disulfide linkages formed during the polymerization step is small, which is consistent with results concerning aggregation and reactivity to free $\mathrm{SH}$; and 2) said disulfide linkages have a negligible effect on gel rheology. Since $G^{\prime}$ is related to the degree of cross-linking, this suggests the presence of additional cross-links in the COV treated sample (Eissa, 2005), when compared with MEF sample.

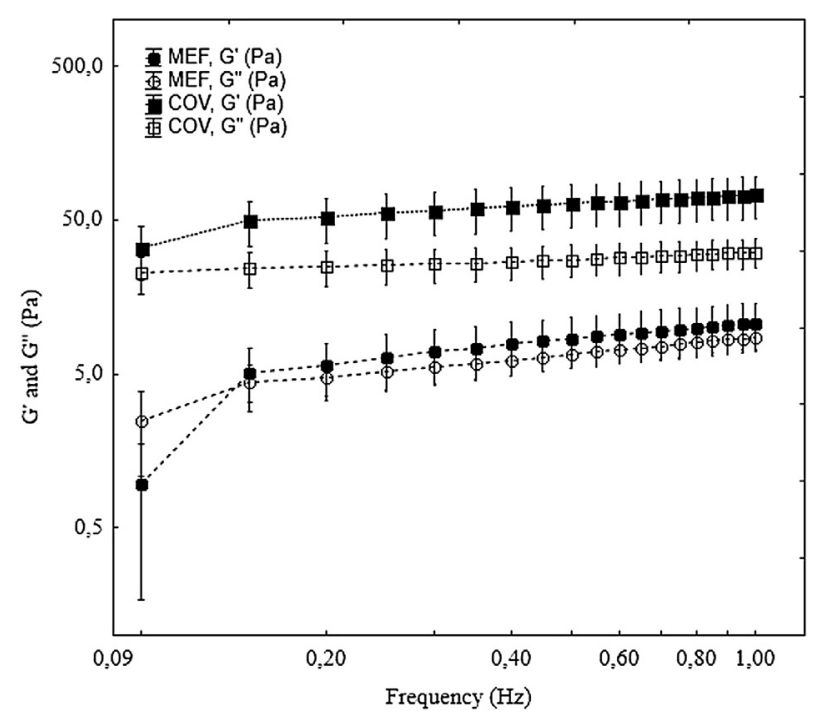

Fig. 5. Viscoelastic behavior of WPI $10 \%(w / w)$ gels obtained through conventional (COV) and moderate electric fields (MEF) heating, at a holding temperature and a holding time of $85{ }^{\circ} \mathrm{C}$ and $30 \mathrm{~min}$, respectively. Closed symbols correspond to the storage modulus $\left(G^{\prime}\right)$ and open symbols to the loss modulus $\left(G^{\prime \prime}\right)$. Squares correspond to COV gels, and circles to MEF gels. The oscillation stress amplitude was set at $0.1 \%$ and the frequency at $1 \mathrm{~Hz}$. Each frequency sweep represents the mean average of triplicated experiments.

During the initial stages of heating gelation, a transition from the protein native to a "progel" state occurs, and this is associated with unfolding and denaturation of the protein. The progel state is usually a viscous liquid state in which some degree of protein
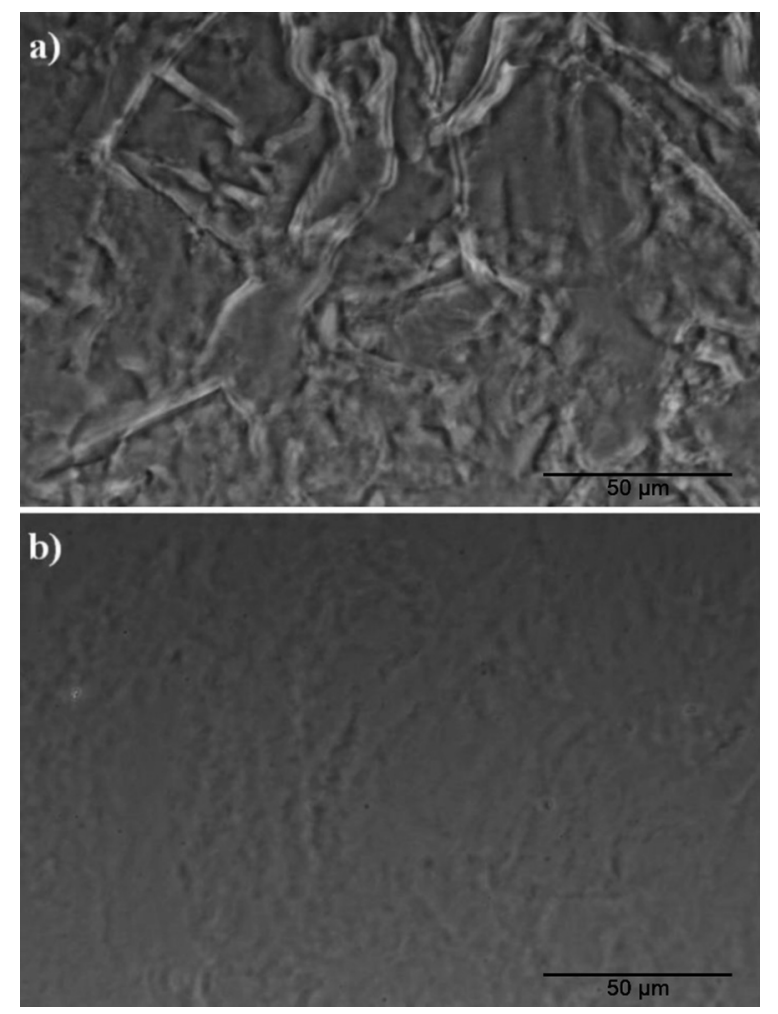

Fig. 6. Phase contrast micrograph at $40 \times$ magnification of WPI gels obtained through: a) conventional (COV) and b) moderate electric fields (MEF) heating, at a holding temperature and time of $85{ }^{\circ} \mathrm{C}$ and $30 \mathrm{~min}$, respectively. Scale bar corresponds to $50 \mu \mathrm{m}$. 
polymerization has already occurred (Geara, 1999). Therefore, it can be suggested that a progel state was achieved at the end of MEF treatment. This progel or liquid-like state was made apparent by the fact that $G^{\prime \prime}$ was not dominated by $G^{\prime}$ during small amplitude oscillatory dynamic measurements at $25{ }^{\circ} \mathrm{C}$ (see Fig. 5).

Our results show that slight differences at nano-scale on the patterns of denaturation/aggregation have a great impact on physical properties of protein network structures. Aggregation and cross-linking patterns of whey proteins during MEF were not sufficiently high to form a true elastic gel network. Weaker gels with different dynamic viscoelastic behavior could be obtained under MEF. Furthermore, it was shown that lower levels of $\alpha$-lac denaturation can be obtained during the early stages of MEF treatments. This may influence the gelation and the viscoelastic behavior of the MEF gels.

It has been reported that increasing the proportion of $\alpha$-lac in protein solutions results in gels characterized by an open microstructure and reduced elastic and viscous moduli (Rabiey \& Britten, 2009). These observations were also supported by phase-contrast light microscopy analyses. Fig. 6 shows the microstructure of the WPI gels produced. MEF gels exhibited a smooth and homogeneous appearance; whereas COV gels presented a well visible heterogeneous appearance, probably due to the presence of a more irregular and compact protein network structures.

\subsection{Non-thermal effects of MEF}

It is important to emphasize the lack of information pertaining to non-thermal effects of MEF on whey protein aggregation mechanisms. The presence of MEF, coupled with temperature may affect molecular flexibility or stability of whey proteins, and therefore aggregation -, likely in the same way of other extrinsic factors, e.g. pH and ionic strength (Sava et al., 2005). MEF may imply conformational disturbances on tertiary protein structure due to rearrangement of hydrogen bonds, hydrophobic interactions and ionic bonds.

During aggregation, application of an alternating electric field may also interfere with electrostatic interactions that play a major role in folding, conformational stability and protein-protein interactions (Neves-Petersen \& Petersen, 2003). Non-covalent interactions may be impaired in the reorientation of hydrophobic clusters occurring in protein structure during application of MEF, thus affecting physical aggregation and gelation. This hypothesis is also supported by the differences found in SH crosslink between treatments (see Fig. 1), which were not as significant as the COV and MEF gels structures suggest (see Fig. 5). This indicates that MEF treatment may affect other kinds of interactions. Application of electric fields may also affect ionic movement in the medium, and modify the molecular environment due to the increased number of ions and their different distributions around the protein molecules (Castro, Macedo, Teixeira, \& Vicente, 2004). Alternatively, the combined effects of MEF and sinusoidal frequency may promote splitting of large aggregates induced by thermal processing, thus enhancing the formation of small particles.

\section{Conclusions}

Heat-induced whey protein denaturation and aggregation is an important phenomenon that has been linked to milk fouling of heat exchangers, among other examples. There is still much to understand on the influence of heat upon the functional properties of whey proteins, especially because these depend on how the heat treatment is applied. Experimental data showed that MEF at $85^{\circ} \mathrm{C}$ (at low ionic strength and neutral $\mathrm{pH}$ ) produced a less extended denaturation of $\beta-\lg A$ during early stages of heating, when compared with indirect heating. It is thus possible to conclude that not only unfolding and denaturation is reduced by MEF, but also size of the aggregates is smaller and remains always below that of the corresponding COV treatments. In addition, these lower rates of denaturation and aggregation may impose significant changes in the gelation mechanisms of whey proteins.

Together with other factors such as $\mathrm{pH}$, ionic strength, protein concentration and the type of heating method (direct or indirect) used for protein denaturation should not be underestimated, once they may influence the viscoelastic dynamic behavior of gels. Nonthermal effects due to the presence of an electrical field must be taken into account during aggregation step of whey proteins; the alternating movement of electrical charges seems to disturb noncovalent interactions between proteins, thus leading to formation of gels with distinct viscoelastic behavior. However, a more complete study is in order for a better understanding of how the electric field interacts, at a molecular level, with individual whey proteins, so as to clarify the events occurring during unfolding, aggregation and gelation steps.

Heating combined with application of MEF may affect quality, as well as functional and technological properties of whey-derived products. Moreover, application of MEF during heating treatment may offer a great potential for development of GRAS (generally recognized as safe) whey protein hydrogels - with diverse mechanical and microstructural features, and thus improved textural properties.

\section{Acknowledgments}

Ricardo N. Pereira and Oscar L. Ramos gratefully acknowledge their Post-Doctoral grants (SFRH/BPD/81887/2011 and SFRH/BPD/ 80766/2011, respectively) by Fundação para a Ciência e Tecnologia (FCT, Portugal). The authors thank the FCT Strategic Project PEstOE/EQB/LA0023/2013 and the project "BioInd - Biotechnology and Bioengineering for improved Industrial and Agro-Food processes", REF. NORTE-07-0124-FEDER-000028 Co-funded by the Programa Operacional Regional do Norte (ON.2 - O Novo Norte), QREN, FEDER.

\section{Appendix A}

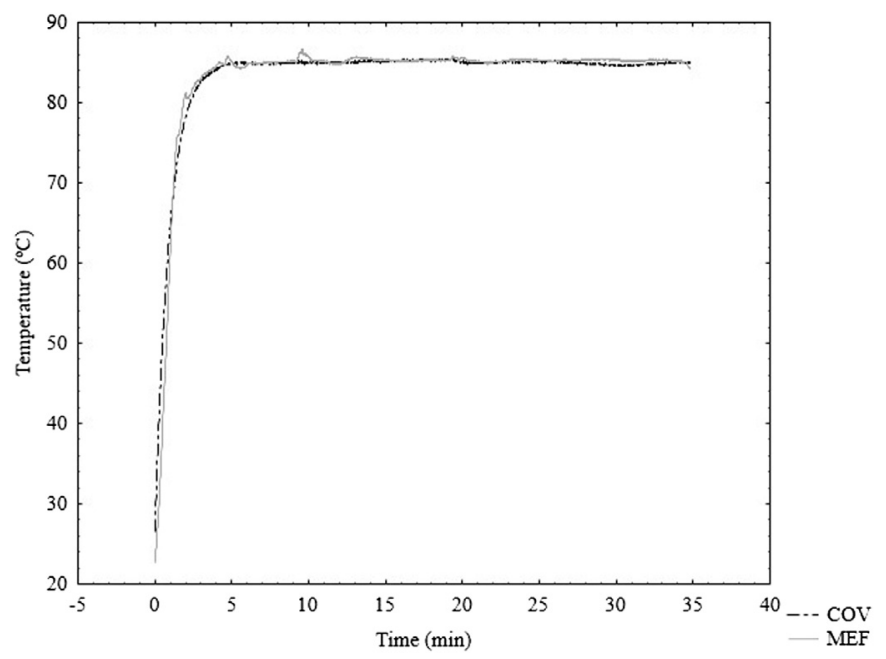

Fig. A.1. Example of heating rate and holding time of thermal treatments applied at $85^{\circ} \mathrm{C}$, for conventional (COV) and moderate electric fields (MEF) heating. 

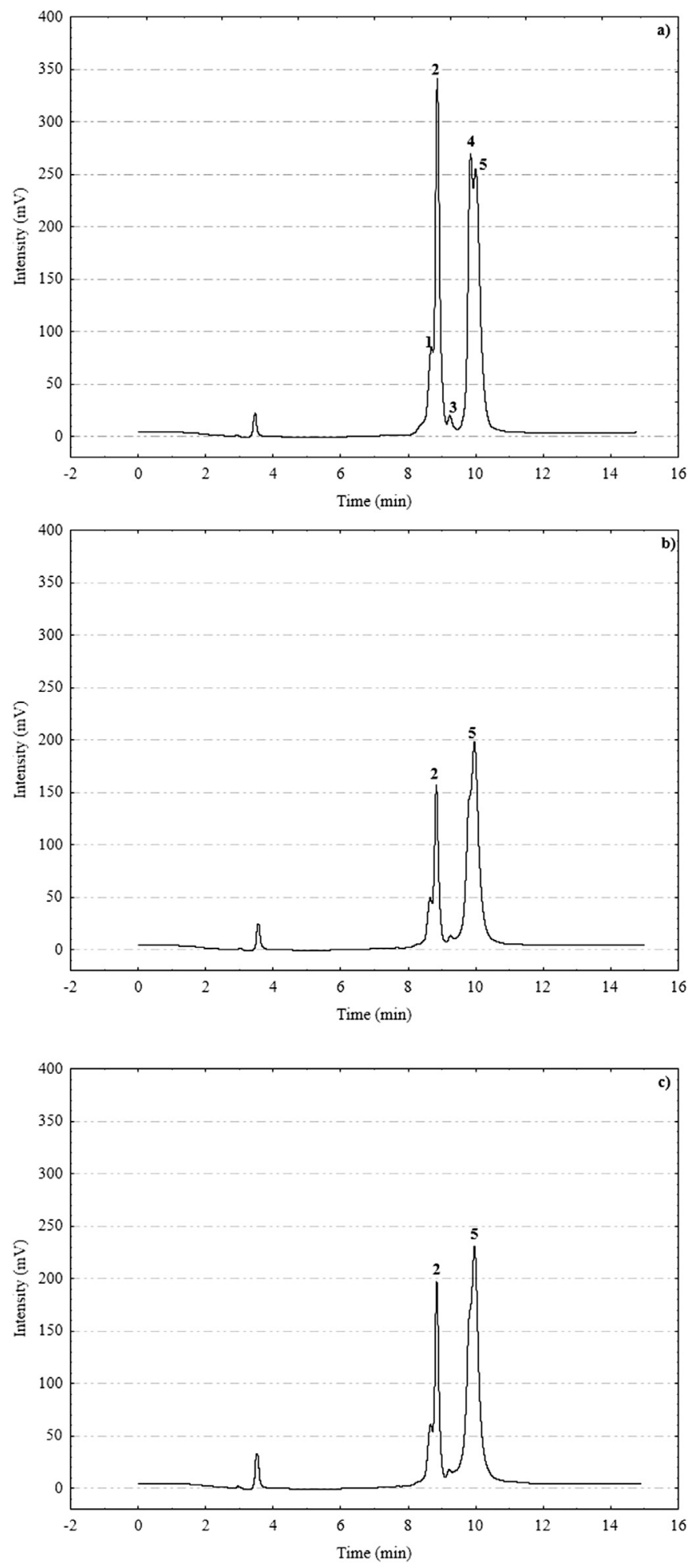

Fig. A.2. Example of chromatograms obtained for unheated (a), and heated WPI samples at $85^{\circ} \mathrm{C}$ through conventional (COV) (b) and moderate electric fields (MEF) (c) heating, for a holding time of $30 \mathrm{~s}$ : (1) BSA; (2) $\alpha$-lac; (3) immunoglobulins (IG); (4) $\beta$ $\lg B$; and (5) $\beta-\lg A$.

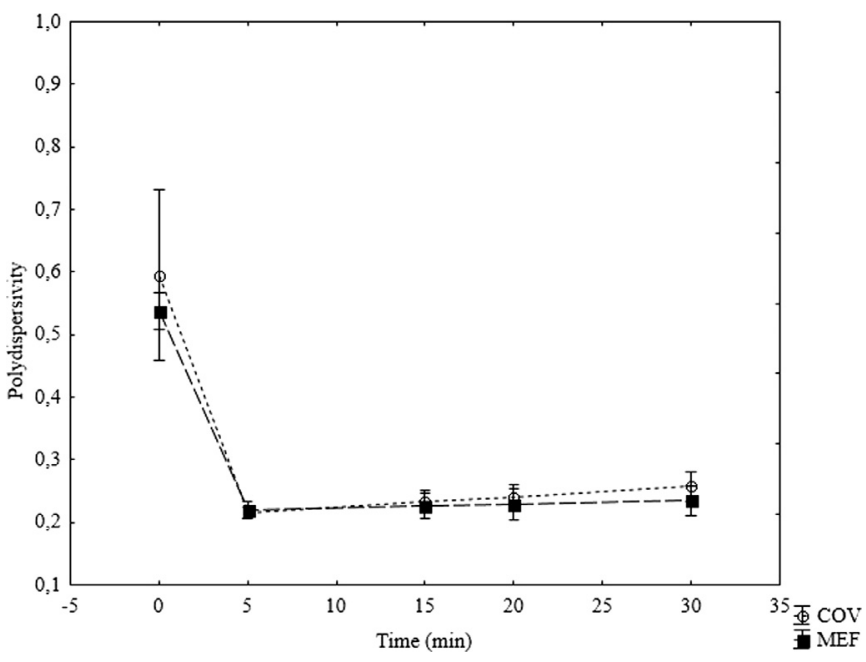

Fig. A.3. Polydispersity index (PDI) of whey protein aggregates as a function of heating holding time, during conventional (COV) and moderate electric fields (MEF) heating, at a holding temperature of $85^{\circ} \mathrm{C}$.

\section{References}

Aboshama, K., \& Hansen, A. P. (1977). Effect of ultra-high-temperature steam injection processing on sulfur-containing amino-acids in milk. Journal of Dairy Science, 60(9), 1374-1378.

Anema, S. G., \& Li, Y. M. (2003). Association of denatured whey proteins with casein micelles in heated reconstituted skim milk and its effect on casein micelle size. Journal of Dairy Research, 70(1), 73-83.

Anema, S. G., \& McKenna, A. B. (1996). Reaction kinetics of thermal denaturation of whey proteins in heated reconstituted whole milk. Journal of Agricultural and Food Chemistry, 44(2), 422-428.

Apenten, R. K. O., Khokhar, S., \& Galani, D. (2002). Stability parameters for betalactoglobulin thermal dissociation and unfolding in phosphate buffer at $\mathrm{pH}$ 7.0. Food Hydrocolloids, 16(2), 95-103.

Aymard, P., Nicolai, T., Durand, D., \& Clark, A. (1999). Static and dynamic scattering of $\beta$-lactoglobulin aggregates formed after heat-induced denaturation at $\mathrm{pH} 2$. Macromolecules, 32(8), 2542-2552.

Castro, I., Macedo, B., Teixeira, J. A., \& Vicente, A. A. (2004). The effect of electric field on important food-processing enzymes: comparison of inactivation kinetics under conventional and ohmic heating. Journal of Food Science, 69(9), C696-C701.

Castro, I., Teixeira, J. A., Salengke, S., Sastry, S. K., \& Vicente, A. A. (2003). The influence of field strength, sugar and solid content on electrical conductivity of strawberry products. Journal of Food Process Engineering, 26(1), 17-29.

Cho, Y. H., Singh, H., \& Creamer, L. K. (2003). Heat-induced interactions of betalactoglobulin A and kappa-casein B in a model system. Journal of Dairy Research, 70(1), 61-71.

Cosio, M. S., Mannino, S., \& Buratti, S. (2000). Electrochemical sensor detecting free sulfhydryl groups: evaluation of milk heat treatment. Journal of Dairy Science, 83(9), 1933-1938.

Croguennec, T., O'Kennedy, B. T., \& Mehra, R. (2004). Heat-induced denaturation aggregation of beta-lactoglobulin A and B: kinetics of the first intermediates formed. International Dairy Journal, 14(5), 399-409.

Dalgleish, D. G., \& Banks, J. M. (1991). The formation of complexes between serum proteins and fat globules during heating of whole milk. Milchwissenschaft Milk Science International, 46, 75-78.

Dannenberg, F., \& Kessler, H. G. (1988). Reaction-kinetics of the denaturation of whey proteins in milk. Journal of Food Science, 53(1), 258-263.

De Alwis, A. A. P., \& Fryer, P. J. (1990). A finite-element analysis of heat generation and transfer during ohmic heating of food. Chemical Engineering Science, 45(6), $1547-1559$.

Eissa, A. S. (2005). Enzymatic modification of whey protein gels at low pH (PhD thesis). Raleigh: North Carolina State University.

Ellman, G. L. (1959). Tissue sulfhydryl groups. Archives of Biochemistry and Biophysics, 82(1), 70-77.

Errington, A. D., \& Foegeding, E. A. (1998). Factors determining fracture stress and strain of fine-stranded whey protein gels. Journal of Agricultural and Food Chemistry, 46(8), 2963-2967.

Fairley, P., Monahan, F. J., German, J. B., \& Krochta, J. M. (1996). Mechanical properties and water vapor permeability of edible films from whey protein isolate and N-ethylmaleimide or cysteine. Journal of Agricultural and Food Chemistry, 44(12), 3789-3792.

Ferreira, I. M., Mendes, E., \& Ferreira, M. A. (2001). HPLC/UV analysis of proteins in dairy products using a hydrophobic interaction chromatographic column. Analytical Sciences, 17(4), 499-501. 
Geara, C. (1999). Study of the gelation of whey protein isolate by FTIR spectroscopy and rheological measurements (Master thesis). Montreal, Canada: Macdonald Campus of McGill University.

Gimel, J. C., Durand, D., \& Nicolai, T. (1994). Structure and distribution of aggregates formed after heat-induced denaturation of globular proteins. Macromolecules, 27(2), 583-589.

Glibowski, P., Mleko, S., \& Wesolowska-Trojanowska, M. (2006). Gelation of single heated vs. double heated whey protein isolate. International Dairy Journal, 16(9), $1113-1118$.

Gordon, L., \& Pilosof, A. (2010). Application of high-intensity ultrasounds to control the size of whey proteins particles. Food Biophysics, 5(3), 203-210.

Grácia-Juliá, A., René, M., Cortés-Muñoz, M., Picart, L., López-Pedemonte, T. Chevalier, D., et al. (2008). Effect of dynamic high pressure on whey protein aggregation: a comparison with the effect of continuous short-time thermal treatments. Food Hydrocolloids, 22(6), 1014-1032.

Havea, P., Singh, H., \& Creamer, L. K. (2002). Heat-induced aggregation of whey proteins: comparison of cheese WPC with acid WPC and relevance of mineral composition. Journal of Agricultural and Food Chemistry, 50(16) 4674-4681.

Havea, P. Singh, H., Creamer, L. K., \& Campanella, O. H. (1998). Electrophoretic characterization of the protein products formed during heat treatment of whey protein concentrate solutions. Journal of Dairy Research, 65(1), 79-91.

Hoffmann, M. A. M., Roefs, S. P. F. M., Verheul, M., VanMil, P. J. J. M., \& DeKruif, K. G. (1996). Aggregation of beta-lactoglobulin studied by in situ light scattering. Journal of Dairy Research, 63(3), 423-440.

Hong, Y. H., \& Creamer, L. K. (2002). Changed protein structures of bovine betalactoglobulin B and alpha-lactalbumin as a consequence of heat treatment. International Dairy Journal, 12(4), 345-359.

Ikeda, S., \& Morris, V. J. (2002). Fine-stranded and particulate aggregates of heatdenatured whey proteins visualized by atomic force microscopy. Biomacromolecules, 3(2), 382-389.

Kavanagh, G. M., Clark, A. H., \& Ross-Murphy, S. B. (2000). Heat-induced gelation of globular proteins: part 3. Molecular studies on low $\mathrm{pH}$ [beta]-lactoglobulin gels. International Journal of Biological Macromolecules, 28(1), 41-50.

Kazmierski, M., \& Corredig, M. (2003). Characterization of soluble aggregates from whey protein isolate. Food Hydrocolloids, 17(5), 685-692.

Koka, M., Mikolajcik, M. E., \& Gould, I. A. (1968). Spectrophotometric method for determination of heat-activated sulfhydryl groups of skimmilk. Journal of Dairy Science, 51(2), 217-219.

Kroslak, M., Sefcik, J., \& Morbidelli, M. (2007). Effects of temperature, pH, and salt concentration on beta-lactoglobulin deposition kinetics studied by optical waveguide lightmode spectroscopy. Biomacromolecules, 8(3), 963-970.

Laligant, A., Dumay, E., Valencia, C. C., Cuq, J. L., \& Cheftel, J. C. (1991). Surface hydrophobicity and aggregation of beta-lactoglobulin heated near neutral $\mathrm{pH}$ Journal of Agricultural and Food Chemistry, 39(12), 2147-2155.

Larson, B. L., \& Rolleri, G. D. (1955). Heat denaturation of the specific serum proteins in milk. Journal of Dairy Science, 38(4), 351-360.

Law, A. J. R., \& Leaver, J. (2000). Effect of pH on the thermal denaturation of whey proteins in milk. Journal of Agricultural and Food Chemistry, 48(3), 672-679.

Lefevre, T., Subirade, M., \& Pezolet, M. (2005). Molecular description of the formation and structure of plasticized globular protein films. Biomacromolecules, 6(6), 3209-3219.

Lin, S., Sun, J., Cao, D., Cao, J., \& Jiang, W. (2010). Distinction of different heat-treated bovine milks by native-PAGE fingerprinting of their whey proteins. Food Chemistry, 121(3), 803-808.

Lozano, J. M., Giraldo, G. I., \& Romero, C. M. (2008). An improved method for isolation of [beta]-lactoglobulin. International Dairy Journal, 18(1), 55-63.

Machado, L. F., Pereira, R. N., Martins, R. C., Teixeira, J. A., \& Vicente, A. A. (2010). Moderate electric fields can inactivate Escherichia coli at room temperature. Journal of Food Engineering, 96(4), 520-527.

Mahmoudi, N., Mehalebi, S., Nicolai, T., Durand, D., \& Riaublanc, A. (2007). Lightscattering study of the structure of aggregates and gels formed by heatdenatured whey protein isolate and $\beta$-lactoglobulin at neutral $\mathrm{pH}$. Journal of Agricultural and Food Chemistry, 55(8), 3104-3111.

Manderson, G. A., Hardman, M. J., \& Creamer, L. K. (1998). Effect of heat treatment on the conformation and aggregation of beta-lactoglobulin A, B, and C. Journal of Agricultural and Food Chemistry, 46(12), 5052-5061.

Mulvihill, D. M., Rector, D., \& Kinsella, J. E. (1990). Effects of structuring and destructuring anionic ions on the rheological properties of thermally induced beta-lactoglobulin gels. Food Hydrocolloids, 4(4), 267-276.

Neves-Petersen, M. T., \& Petersen, S. B. (2003). Protein electrostatics: a review of the equations and methods used to model electrostatic equations in biomolecules applications in biotechnology. In Biotechnology annual review (Vol. 9); (pp. 315-395). Elsevier.

Nicorescu, I. Loisel, C., Vial, C., Riaublanc, A., Djelveh, G., Cuvelier, G., et al. (2008) Combined effect of dynamic heat treatment and ionic strength on denaturation and aggregation of whey proteins - part I. Food Research International, 41(7), $707-713$.

Nielsen, B. T., Singh, H., \& Latham, J. M. (1996). Aggregation of bovine betalactoglobulins A and B on heating at 75 degrees C. International Dairy Journal, 6(5), 519-527.
Oldfield, D. J., Singh, H., Taylor, M. W., \& Pearce, K. N. (1998). Kinetics of denaturation and aggregation of whey proteins in skim milk heated in an ultra-high temperature (UHT) pilot plant. International Dairy Journal, 8(4), 311-318.

Otte, J., Zakora, M., \& Qvist, K. B. (2000). Involvement of disulfide bonds in bovine $\beta$ lactoglobulin B gels set thermally at various pH. Journal of Food Science, 65(3), 384-389.

Owusu-Apenten, R. (2005). Colorimetric analysis of protein sulfhydyl groups in milk: applications and processing effects. Critical Reviews in Food Science and Nutrition, 45(1), 1-23.

Owusu-Apenten, R., \& Chee, C. (2004). Sulfhydryl group activation for commercial beta-lactoglobulin measured using kappa-casein 2-thio, 5' nitrobenzoic acid. International Dairy Journal, 14(3), 195-200.

Parrot, D. (1992). Use of ohmic heating for aseptic processing of food particulates. Food Technology (Chicago, IL, U. S.), 46(12), 68-72.

Pásztor-Huszár, K. (2008). Protein changes of various types of milk as affected by high hydrostatic pressure processing (PhD thesis). Budapest: Corvinus University of Budapest.

Pataro, G., Barca, G. M. J., Pereira, R. N., Vicente, A. A., Teixeira, J. A., \& Ferrari, G. (2014). Quantification of metal release from stainless steel electrodes during conventional and pulsed ohmic heating. Innovative Food Science \& Emerging Technologies, 21, 66-73.

Pereira, R. N., Souza, B. W. S., Cerqueira, M. A., Teixeira, J. A., \& Vicente, A.n. A. (2010). Effects of electric fields on protein unfolding and aggregation: influence on edible films formation. Biomacromolecules, 11(11), 2912-2918.

Pereira, R. N., Teixeira, J. A., \& Vicente, A. A. (2011). Exploring the denaturation of whey proteins upon application of moderate electric fields: a kinetic and thermodynamic study. Journal of Agricultural and Food Chemistry, 59(21), 11589-11597.

Pinto, J., Silva, V. L. M., Silva, A. M. G., Silva, A. M. S., Costa, J. C. S., Santos, L. M. N. B. F., et al. (2013). Ohmic heating as a new efficient process for organic synthesis in water. Green Chemistry, 15(4), 970-975.

Purwanti, N., Smiddy, M., Jan van der Goot, A., de Vries, R., Alting, A., \& Boom, R. (2011). Modulation of rheological properties by heat-induced aggregation of whey protein solution. Food Hydrocolloids, 25(6), 1482-1489.

Rabiey, L., \& Britten, M. (2009). Effect of protein composition on the rheological properties of acid-induced whey protein gels. Food Hydrocolloids, 23(3), 973-979.

Roefs, S. P. F. M., \& De Kruif, K. G. (1994). A model for the denaturation and aggregation of $\beta$-lactoglobulin. European Journal of Biochemistry, 226(3), 883-889.

Ryan, K. N., Vardhanabhuti, B., Jaramillo, D. P., van Zanten, J. H., Coupland, J. N., \& Foegeding, E. A. (2012). Stability and mechanism of whey protein soluble aggregates thermally treated with salts. Food Hydrocolloids, 27(2), 411-420.

Sava, N., Van der Plancken, I., Claeys, W., \& Hendrickx, M. (2005). The kinetics of heat-induced structural changes of $\beta$-lactoglobulin. Journal of Dairy Science, 88(5), 1646-1653.

Schmitt, C., Bovay, C., Rouvet, M., Shojaei-Rami, S., \& Kolodziejczyk, E. (2007). Whey protein soluble aggregates from heating with $\mathrm{NaCl}$ : physicochemical, interfacial, and foaming properties, Langmuir, 23(8), 4155-4166.

Schmitt, C., Bovay, C., Vuilliomenet, A. M., Rouvet, M., Bovetto, L., Barbar, R., et al. (2009). Multiscale characterization of individualized beta-lactoglobulin microgels formed upon heat treatment under narrow pH range conditions. Langmuir, 25(14), 7899-7909.

Schokker, E. P., Singh, H., Pinder, D. N., \& Creamer, L. K. (2000). Heat-induced aggregation of beta-lactoglobulin $\mathrm{AB}$ at $\mathrm{pH} 2.5$ as influenced by ionic strength and protein concentration. International Dairy Journal, 10(4), 233-240.

Schokker, E. P., Singh, H., Pinder, D. N., Norris, G. E., \& Creamer, L. K. (1999). Characterization of intermediates formed during heat-induced aggregation of [beta]-lactoglobulin $\mathrm{AB}$ at neutral pH. International Dairy Journal, 9(11), 791-800.

Sharma, M., Haque, Z. U., \& Wilson, W. W. (1996). Association tendency of [beta]lactoglobulin $\mathrm{AB}$ purified by gel permeation chromatography as determined by dynamic light scattering under quiescent conditions. Food Hydrocolloids, $10(3), 323-328$

Shimada, K., \& Cheftel, J. C. (1989). Sulfhydryl-group disulfide bond interchange reactions during heat-induced gelation of whey-protein isolate. Journal of Agricultural and Food Chemistry, 37(1), 161-168.

Tolkach, A., \& Kulozik, U. (2005). Effect of pH and temperature on the reaction kinetic parameters of the thermal denaturation of beta-lactoglobulin. Milchwissenschaft - Milk Science International, 60(3), 249-252.

Vardhanabhuti, B., \& Foegeding, E. A. (1999). Rheological properties and characterization of polymerized whey protein isolates. Journal of Agricultural and Food Chemistry, 47(9), 3649-3655.

Vardhanabhuti, B., Foegeding, E. A., McGuffey, M. K., Daubert, C. R., \& Swaisgood, H. E. (2001). Gelation properties of dispersions containing polymerized and native whey protein isolate. Food Hydrocolloids, 15(2), 165-175.

Verheul, M., Roefs, S. P. F. M., \& de Kruif, K. G. (1998). Kinetics of heat-induced aggregation of beta-lactoglobulin. Journal of Agricultural and Food Chemistry, 46(3), 896-903.

Wehbi, Z., Perez, M. D., Sanchez, L., Pocovi, C., Barbana, C., \& Calvo, M. (2005). Effect of heat treatment on denaturation of bovine alpha-lactalbumin: determination of kinetic and thermodynamic parameters. Journal of Agricultural and Food Chemistry, 53(25), 9730-9736. 